A C G publications

Rec. Nat. Prod. 12:3 (2018) 273-283

records of natural products

\title{
Inhibition of Various Cancer Cells Proliferation of Bornyl Acetate and Essential Oil from Inula graveolens (Linnaeus) Desf.
}

\author{
Tunay $\operatorname{Karan}^{1}{ }^{1}$, Ilyas Yildiz $\odot^{2}$, Ali Aydin $\odot^{3}$ and Ramazan Erenler $\odot^{2 *}$ \\ ${ }^{1}$ Department of Molecular Biology and Genetics, Faculty of Arts and Sciences, Gaziosmanpasa \\ University, 60240 Tokat, Türkiye \\ ${ }^{2}$ Department of Chemistry, Faculty of Arts and Sciences, Gaziosmanpasa University, 60240 Tokat, \\ Türkiye \\ ${ }^{3}$ Department of Biotechnology, Faculty of Science, Bartın University, 74100 Bartın, Türkiye
}

(Received September 26, 2017; Revised October 24, 2017; Accepted October 28, 2017)

\begin{abstract}
Inula species are medicinal and aromatic plants used for folk medicine extensively. In this work, hydrodistilled essential oil of Inula graveolens (Linnaeus) Desf. analyzed by GC-MS which revealed that bornyl acetate was the major product $(69.15 \%)$. Camphene was the second major compound $(11.11 \%)$. Antiproliferative activity of the essential oil and bornyl acetate was investigated on HeLa (human cervix carcinoma), HT29 (human colon carcinoma), A549 (human lung carcinoma), MCF7 (human breast adenocarcinoma) cancer cells and FL (human amnion cells) normal cells. The cytotoxicity was executed by a Lactate Dehydrogenase (LDH) Cytotoxicity Detection Kit. Essential oil and bornyl acetate displayed the outstanding activities on HeLa ( IC $_{50}$, 64.1, $72.0 \mu \mathrm{g} / \mathrm{mL}), \mathrm{HT} 29\left(\mathrm{IC}_{50}, 24.6,60.5 \mu \mathrm{g} / \mathrm{mL}\right)$, A549 (IC $\left.{ }_{50}, 28.3,44.1 \mu \mathrm{g} / \mathrm{mL}\right)$, MCF-7 ( $\mathrm{IC}_{50}, 66.5,85.6$ $\mu \mathrm{g} / \mathrm{mL})$, and $\mathrm{FL}\left(\mathrm{IC}_{50}, 42.1,50.6 \mu \mathrm{g} / \mathrm{mL}\right)$ cell lines respectively.
\end{abstract}

Keywords: Inula graveolens; essential oil; antitumor activity. (c) 2018 ACG Publications. All rights reserved.

\section{Introduction}

Plants which have been used in treatment of various illness for centuries play a significant role in drug discovery due to the consisting of bioactive compounds [1-3]. Inula genus belonging to Asteraceae family consists of almost 100 species distributed through Africa, Asia and Europe, mostly in the Mediterranean area. It is represented by 27 species with 7 endemic species in Turkey flora [4]. Plants of this genus revealed high variety in secondary metabolites and pharmaceutical effects [5]. Inula graveolens (L.) Desf. [Syn. Dittrichia graveolens. (Desf.) Greuter] is an annual herb, growing 20-50 cm tall, well known and wide spread in the Mediterranean area with pleasant odor [6]. Inula species have been used in traditional medicine throughout the world extensively. Hence, Commercial herbal preparations of Inula species were available, such as Inula japonica on herbal supplement tablet [7] and Inula helenium on the antiulcerous drug tablet [8] and some of them are recorded in European pharmacopoeias [8]. The secondary metabolites as well as extract from Inula species revealed a broad spectrum of biological and pharmaceutical activities including antioxidant [9], antiproliferative [10, 11] , cardioprotective [12], antiinflammatory[13], antipyretic, antiphlogistic, antiseptic [14], antifungal [15], antibacterial [16], insecticidal, antifeedant [17], nematicidal activity [18]. Phytochemical

*Corresponding author: E-Mail:ramazan.erenler@gop.edu.tr; Phone:090-356-2521616/3055 Fax:90-3562521585 
investigation on Inula species resulted in the isolation of bioactive secondary metabolites such as eudesmanolides [19], guaianolides [20], pseudoguaianolides [21], xanthanolides [22], dimeric sesquiterpenes [23], flavonoids [24]. Inula graveolens essential oil has a significant pharmaceutical effects containing antimicrobial [25], anticandida [26], acetylcholinesterase (AChE) inhibitory activities [27]. I. graveolens collected from Algeria included the isobornylacetate (50.8\%) as a main constituent [28]. A sesquiterpene and ilicic acid isolated from Inula graveolens displayed the selective and significant phytotoxic activity [29]. In addition, sesquiterpenes and flavones were isolated from $I$. graveolens $[30,31]$.

Cancers, a group of diseases described as uncontrolled cell growth and spread is the leading cause of deaths throughout the world. Due to the rising trend of cancer incidence, efficient treatment is urgently necessary to control tumor-cell proliferation. Therefore, new chemotherapeutic molecules are significant to deal with this catastrophic issue. Natural products have been acknowledged to a great medicine to prevent or suppress the progression of invasive cancers[32].

Herein, essential oil was generated by steam distillation and the components were identified by GC-MS analyses. Antiproliferative activity of essential oil and bornyl acetate which was the main constituent of essential oil of I. graveolens was investigated on HeLa (human cervix carcinoma), HT29 (human colon carcinoma), A549 (human lung carcinoma), MCF-7 (human breast adenocarcinoma) cancer cells and FL (human amnion cells) normal cells. The cytotoxicity was executed by a Lactate Dehydrogenase (LDH) Cytotoxicity Detection Kit. Essential oil and bornyl acetate displayed the considerable activity on these cell lines.

\section{Materials and Methods}

\subsection{General Experimental Procedure}

Dulbecco's modified Eagle's medium-high glucose (DMEM-HG), fetal bovine serum (FBS), penicillin/streptomycin were supplied from Sigma-Aldrich (Darmstadt, Germany). ELISA and BrdU (colorimetric) kits were obtained from Roche Diagnostics GmbH (Mannheim, Germany). The other solvents and chemicals were used in analytical grade and obtained from E. Merck, Kenilworth, NJ, USA.

\subsection{Plant Materials}

Inula graveolens was collected in July 2015 from Tokat Turkey Provence and identified by Prof. Dr. Ahmet Ilcim, Mustafa Kemal University, Faculty of Arts and Sciences, Department of Biology where a voucher specimen was deposited (No: MKUH-1823).

\subsection{Isolation of Essential Oil}

Aerial parts of the plant material (200 g) were dried at shade then, hydrodistilled for $4 \mathrm{~h}$ using a Clevenger-type apparatus. The distilled essential $(1.5 \%$, w/w) oil was dried over anhydrous sodium sulfate, filtered and stored at $4{ }^{\circ} \mathrm{C}$ to further analyses [33]. Bornyl acetate was purchased commercially from Sigma-Aldrich.

\subsection{GC Analysis}

Perkin-Elmer Clarus 500 model Autosystem GC was used for analysis of essential oil. Oil was diluted with acetone (1:10) then injected to the HT-5 column $(25 \mathrm{~m}, 0.22 \mathrm{~mm}, 0.1 \mu \mathrm{m}$ film). The column temperature was adjusted from 50 to $120{ }^{\circ} \mathrm{C}$ at $3{ }^{\circ} \mathrm{C} / \mathrm{min}$, from 120 to $220{ }^{\circ} \mathrm{C}$, at $5{ }^{\circ} \mathrm{C} / \mathrm{min}$ with initial and final temperatures held for $0.64 \mathrm{~min}$. Helium was used as a carrier gas at 5 psi inlet pressure. Injection and detection (FID) temperature was $250^{\circ} \mathrm{C}$. Sample $(1.0 \mu \mathrm{L})$ was injected into the split/splitless (50:1) mode [34]. 


\subsection{GC-MS analysis}

Perkin-Elmer mass spectrometer with BPXT column $(30 \mathrm{~m} \times 0.25 \mathrm{~mm} \times 0.25 \mu \mathrm{m}$ film $)$ was used for analysis of essential oil. An electron ionisation system with ionisation energy of $70 \mathrm{eV}$ was used for GC-MS detection. Helium gas with a flow rate of $1.3 \mathrm{~mL} / \mathrm{min}$ was used for carrier gas. MS transfer line and injector temperatures were set at $250{ }^{\circ} \mathrm{C}$ and $230{ }^{\circ} \mathrm{C}$ respectively. The sample $(1 / 10$ in acetone, $\mathrm{v} / \mathrm{v}, 1.0 \mu \mathrm{L})$ was injected in the split/splitless $(5: 1 \mathrm{split})$ mode. Retention indices were calculated by an $n$-alkane series (C6-C32) with the same GC programme as for the samples. The relative amount (\%) of individual components of the oil is determined as percent peak area relative to total peak area from the GC-FID analyses [34].

\subsection{Cell Cultures Preparation}

Antitumor capacity of essential oil and bornyl acetate which was the main compound of essential oil was investigated on HeLa (human cervix carcinoma), HT29 (human colon carcinoma), A549 (human lung carcinoma), MCF-7 (human breast adenocarcinoma) cancer cells and FL (human amnion cells) normal cells. The cells were incubated in T75 cell culture flasks with Dulbecco' modified eagle's medium, complemented with $10 \%$ fetal bovine serum, $2 \%$ PenStep solution (Penisilin-Streptomisin, Sigma, Germany) and sodium bicarbonate $(0.026 \mathrm{M})$ at $37{ }^{\circ} \mathrm{C}$ with $5 \% \mathrm{CO}_{2}$ for 4 days. Additionally, RPMI1640 medium with sodium bicarbonate $(0.019 \mathrm{M})$ was used for MCF-7 cell lines. After the cells became confluent, they were changed with Tripsin-EDTA (10 mL) solution and incubated for $5 \mathrm{~min}$ then, the flask was shacked slowly to form the suspension of the cells which were conveyed to $50 \mathrm{~mL}$ sterilized falcon tubes. Trypsin was neutralized by adding medium to the cells and cells was centrifuged at $1500 \times \mathrm{g}$ for $10 \mathrm{~min}$. After removal of supernatant part, cell pellets were resuspended by adding $2 \mathrm{~mL}$ medium. $10 \mu \mathrm{L}$ suspended cell was mixed with $10 \mu \mathrm{L}$ trypan blue, then $10 \mu \mathrm{L}$ of this mixture was pipetted to Thoma cell counting chamber to determine the cell concentration. The cell stock suspension was prepared into the $15 \mathrm{~mL}$ of falcon tube, then pippeted into the cell plates $\left(5 \times 10^{3}\right.$ cells/well $)[35,36]$.

\subsection{Cell Proliferation Assay}

Test samples and standard were treated with the cell plates and incubated at $37{ }^{\circ} \mathrm{C}$ for $24 \mathrm{~h}$. Dulbecco's Modified Eagle's Medium (DMEM), DMSO (Dimethyl sulfoxide), 5-Florourasil were used for cell control, negative control and positive control, respectively. BrdU (5-bromo-2'deoxyuridine) Cell Proliferation ELISA kit (Roche) was used for antiproliferative effects. BrDU was added to the flask until the density to be $10 \mu \mathrm{L} /$ well cells then incubated additionally for $4 \mathrm{~h}$. When BrdU was added to medium, BrdU was inserted to DNA of divided cells. Therefore, DNA incorporated with BrdU can help the measurement of the proliferation. The medium with BrdU in plates was removed. Then, Fix Denat solution was added to the cells in plate for cell lysis and incubated at $25^{\circ} \mathrm{C}$ for $30 \mathrm{~min}$. Hence, BrdU-POD antibody can penetrate to the DNA and approach to the BrdU easily. Fix Denat solution was changed with Anti-BrdU-POD solution and incubated at 22 ${ }^{\circ} \mathrm{C}$ for $90 \mathrm{~min}$, afterwards, plate was washed by washing solution and substrate solution was added to set the density as $100 \mu \mathrm{L} /$ well. The flask was incubated at $22{ }^{\circ} \mathrm{C}$ for $30 \mathrm{~min}$ until the appearance of the color. Each well was added sulphuric acid, $\mathrm{H}_{2} \mathrm{SO}_{4}(25 \mu \mathrm{L} 1.0 \mathrm{M})$ and then, the microplate was incubated for $2 \mathrm{~min}$. The proliferation was executed by ELISA reader (Rayto, China) at 450-650 nm [37]. The results were indicated as \% inhibition using the given formula:

$\%$ inhibition $=\left[\frac{\mathrm{A}_{\text {sample }}-\mathrm{A}_{\text {control }}}{\mathrm{A}_{\text {control }}}\right] \times 100$

Where $\mathrm{A}_{\text {sample }}$ is the absorbance of treated cells and $\mathrm{A}_{\text {control }}$ is the absorbance of the untreated cells [38]. 


\subsection{Cytotoxicity Assay}

The cytotoxicity of the bornyl acetate and essential oil and standard was presented through a Lactate Dehydrogenase (LDH) Cytotoxicity Detection Kit (Roche, USA) using the HeLa, HT29, MCF-7, A549 cell lines. LDH technique determines the test materials to be cytotoxic or cytostatic [39]. The increase of the death cells during the incubation in concern the test materials leads the increase of LDH in culture supernatant. Lactate dehydrogenase (LDH) is the cytoplasm enzyme required during the process turning sugar into energy and found in many cells as stable form. About 3 $\times 10^{4}$ cells in $100 \mu \mathrm{L}$ were seeded into 96 -well microtiter plates as triplicates and treated with various concentrations of bornyl acetate and essential oil at $37{ }^{\circ} \mathrm{C}$ with $5 \% \mathrm{CO}_{2}$ overnight. LDH activity was executed by evaluating the absorbance at $492-630 \mathrm{~nm}$ by a microplate reader (RAYTO RT100C). Percentage cytotoxicity was calculated as the given formula:

Cytotoxicity $(\%)=\left[\frac{\text { Exp. value-Low control }}{\text { High control-Low control }}\right] \times 100$

Where experimental value is the treated cells, Low control is untreated cells; High control is $2 \%$ Triton X-100.

\section{$2.9 \mathrm{IC}_{50}$ and Inhibition \%}

The half inhibitory concentration of the bornyl acetate, essential oil and standard was calculated by XLfit5 software (IDBS) and explicated in $\mu \mathrm{M}$ at $95 \%$ confidence levels. The proliferation results were recorded as the percent inhibition of the compounds and control substances [40].

\subsection{Cell Imaging}

Seeded cells in well plates at a density of 5000 cells per well were allowed for $24 \mathrm{~h}$ for attachment. The morphological changes with the treatment of the bornyl acetate and essential oil were appraised by phase contrast microscopy. Images of DMSO, bornyl acetate and essential oil treated cells were recorded during the experimental time using the digital camera attached inverted microscope (Leica 1L 10, Germany) [41].

\subsection{Statistical Analysis}

The statistical analysis was carried out by one-way analysis of variance (one-way ANOVA) tests. SPSS for Windows was used for the statistical analyses. The results are reported as the mean values \pm the SEM of three independent assays, and differences between groups were considered to be significant at $\mathrm{P}<0.05[40]$.

\section{Results and Discussion}

Epidemiological studies revealed that compounds isolated from natural sources may protect against various types of cancers such as prostate, lung, colon and breast malignancies [42]. In addition, essential oils have significant effects on various cancer cell lines [43-47]. In this study, essential oil was generated from Inula graveolens L. Bornyl acetate was the chief compound (Table 1). 
Table 1. Chemical composition of I. graveolens essential oil analyzed by gas chromatography-mass spectrometry

\begin{tabular}{lllll}
\hline No & Compounds & RI [48] & RI & Percent (\%) \\
\hline 1 & $\alpha$-Pinene & 932 & 935 & 0.16 \\
2 & Camphene & 946 & 949 & 4.56 \\
3 & $\beta$-Pinene & 974 & 981 & 0.45 \\
4 & 2,3-dehydro-1,8-cineole & 991 & 998 & 1.77 \\
5 & $\delta$-2-Carene & 1009 & 1015 & 0.41 \\
6 & Borneol & 1165 & 1172 & 11.34 \\
7 & Bornyl acetate & 1284 & 1288 & 60.43 \\
8 & Thymol & 1290 & 1277 & 1.18 \\
9 & $\beta$-Cubebene & 1390 & 1381 & 0.70 \\
10 & $\beta$-Caryophyllene & 1417 & 1402 & 1.00 \\
11 & Lavandulol acetate & 1439 & 1430 & 0.54 \\
12 & Humulene & 1454 & 1448 & 0.53 \\
13 & $\delta$-Cadinene & 1524 & 1533 & 0.24 \\
14 & Caryophyllen oxide & 1582 & 1570 & 11.58 \\
15 & $\delta$-Cadinol & 1636 & 1621 & 4.89 \\
& & & & 99.78 \\
\hline
\end{tabular}

${ }^{a} \mathrm{RI}$ : Retention indices calculated against n-alkanes, \% calculated from FID data and RI of literature values.

Antiproliferative effect of essential oil as well as bornyl acetate was investigated invitro. Antiproliferative effects of bornyl acetate and essential oil of Inula graveolens was investigated on HeLa (human cervix carcinoma), HT-29 (human colon carcinoma), A549 (human lung carcinoma), MCF-7 (human breast adenocarcinoma) cancer cells, and FL (human amnion cells) normal cells (Figure 1).

The cytotoxicity was also carried out by a Lactate Dehydrogenase (LDH) Cytotoxicity Detection method. Due to the chief constituent of essential oil, bornyl acetate was investigated individually as well. In HeLa cell lines, bornyl acetate and essential oil displayed the better activity than that of the standard, cis-platin. Bornyn acetate and essential oil revealed the nearly same inhibitory effect on HeLa cells proliferation depending on the concentration. As a result, the viability of HeLa cells decreased sharply between the concentrations from $40 \mu \mathrm{g} / \mathrm{mL}$ to $60 \mu \mathrm{g} / \mathrm{mL}$. After that point, steady decrease was observed for the viability of these cells. $\mathrm{IC}_{50}$ values of bornyl acetate, essential oil and cis-platin were calculated as 71.97, 64.05 and 126.75 respectively. High inhibitory effect of essential oil than that of the bornyl acetate may be attributed to the synergic effect of the compounds into the essential oil. The same trend was observed in HT-29 cell lines. The steady decrease was observed for the viability of HT-29 cells depending on the concentration. Essential oil showed the better inhibitory effect on the proliferation of HT-29 ( $\left.\mathrm{IC}_{50} 24.6\right)$ cells in all concentrations than that of the bornyl acetate $\left(\mathrm{IC}_{50} 60.5\right)$ and cis-platin (IC50 119.9). This result showed that the essential oil has a capacity of being an anticancer agent. Essential oil revealed the excellent tumor specificity on HT-29 cell lines as well (Table 1). As for the A549 (human lung carcinoma) cancer cells, a significant inhibition effect of essential oil was observed. $\mathrm{IC}_{50}$ values of essential oil, bornyl acetate and cis-platin were $28.3,44.1,131.0$ respectively revealing that essential oil was 4.6 fold effective than that of the cis-platin. 

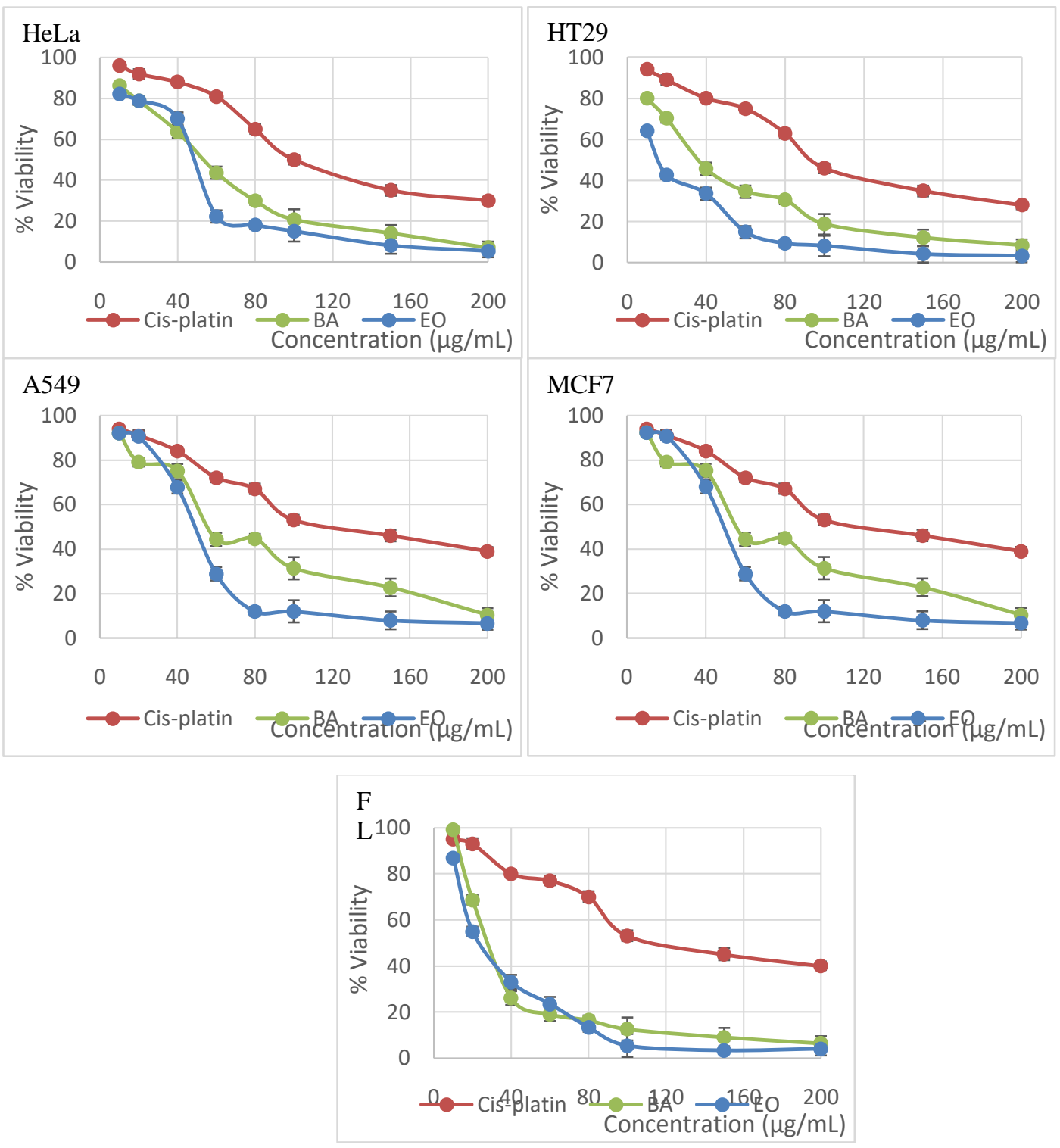

Figure 1. The Antiproliferative activity of bornyl acetate (BA), essential oil (EO) of inula graveolens and positive control, cis-platin on HeLa, HT29, A549, MCF7 and FL cell lines. Cell proliferation was measured using a BrdU Cell Elisa Assay Kit. Percent inhibition was reported as mean values \pm SEM of three independent assays $(\mathrm{P}<0.05)$. Each experiment was repeated at least three times for each cell line.

Essential oil and bornyl acetate showed the greatest tumor specificity on A549 cell lines (Table 1). Essential oil has a considerable inhibition effect on the proliferation of MCF-7 (human breast adenocarcinoma) cancer cells. There was a sharp decrease of viability up to the $80 \mu \mathrm{g} / \mathrm{mL}$. Essential oil showed the superior inhibition effect at all concentration compared to the standard, cisplatin. Bornyl aceate also displayed the better activity than cis-platin. $\mathrm{IC}_{50}$ values of essential oil, bornyl acetate and cis-platin were calculated as 66.5, 85.6, 141.5 respectively. Essential oil and cisplatin have same inhibition effect on FL (human amnion cells) normal cells (Figure 2). A good drug for cancer should not damage to the normmal cells while inhibiting the cancer cells. The disadvantage of essential oil and bornyl acetate was to cause the inhibition of normal cells. The cytotoxicity of bornyl acetate and essential oil as well as standard was determined using a Lactate Dehydrogenase (LDH) Cytotoxicity Detection Kit (Figure 2). 

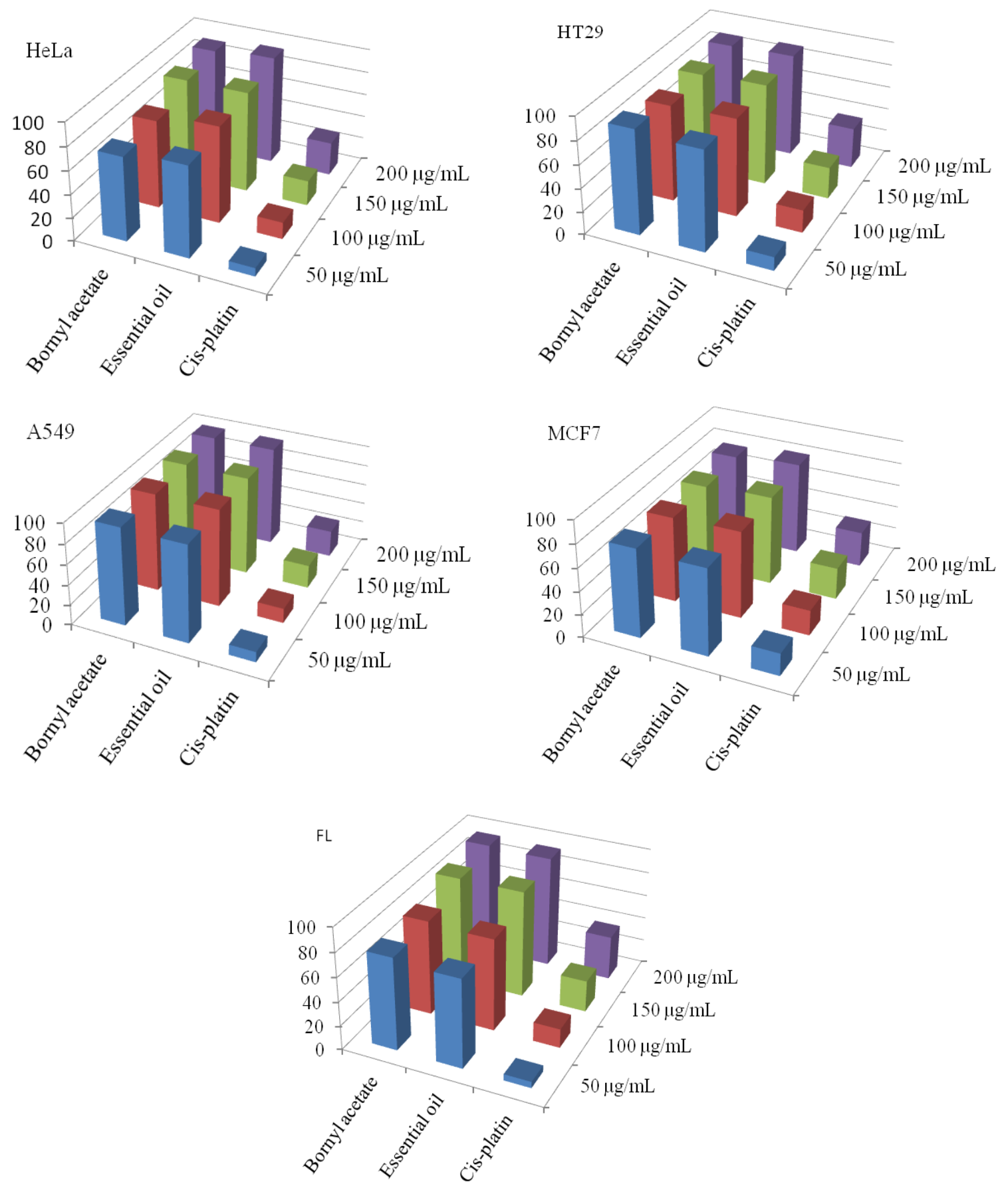

Figure 2. Cytotoxic activity of essential oil, borneol acetate of inula graveolens on HeLa, HT29, A549, MCF7 and FL cell lines. Cell lines were incubated with various concentrations of bornyl acetate and essential oil for 24 hours, and cytotoxicity was determined by LDH Cytotoxicity Assay Kit. Percent cytotoxicity was reported as mean values \pm SDs of three independent assays $(P<0.05)$.

Essential oil and bornyl acetate revealed the higher cytotoxicity than cis-platin on HeLa cells. Same trend was observed on HT-29 cells. For instance, Cytotoxic effect of essential oil and boryn acetate was higher than that of the standard on HT-29 cells. Cytotoxicity of essential oil and bornyl acetate increased with dose dependant manner on A549 cells. Essential oil and bornyl acetate revealed the resemble cytotoxic effect on MCF-7 and FL cells. Treatment of cells with bornyl acetate and 
essential oil brought about disruption and disintegration of cells in general, revealing its cytotoxic effect. Essential oil and bornyl acetate led to cell detachment from the plate surface (Figure 3).

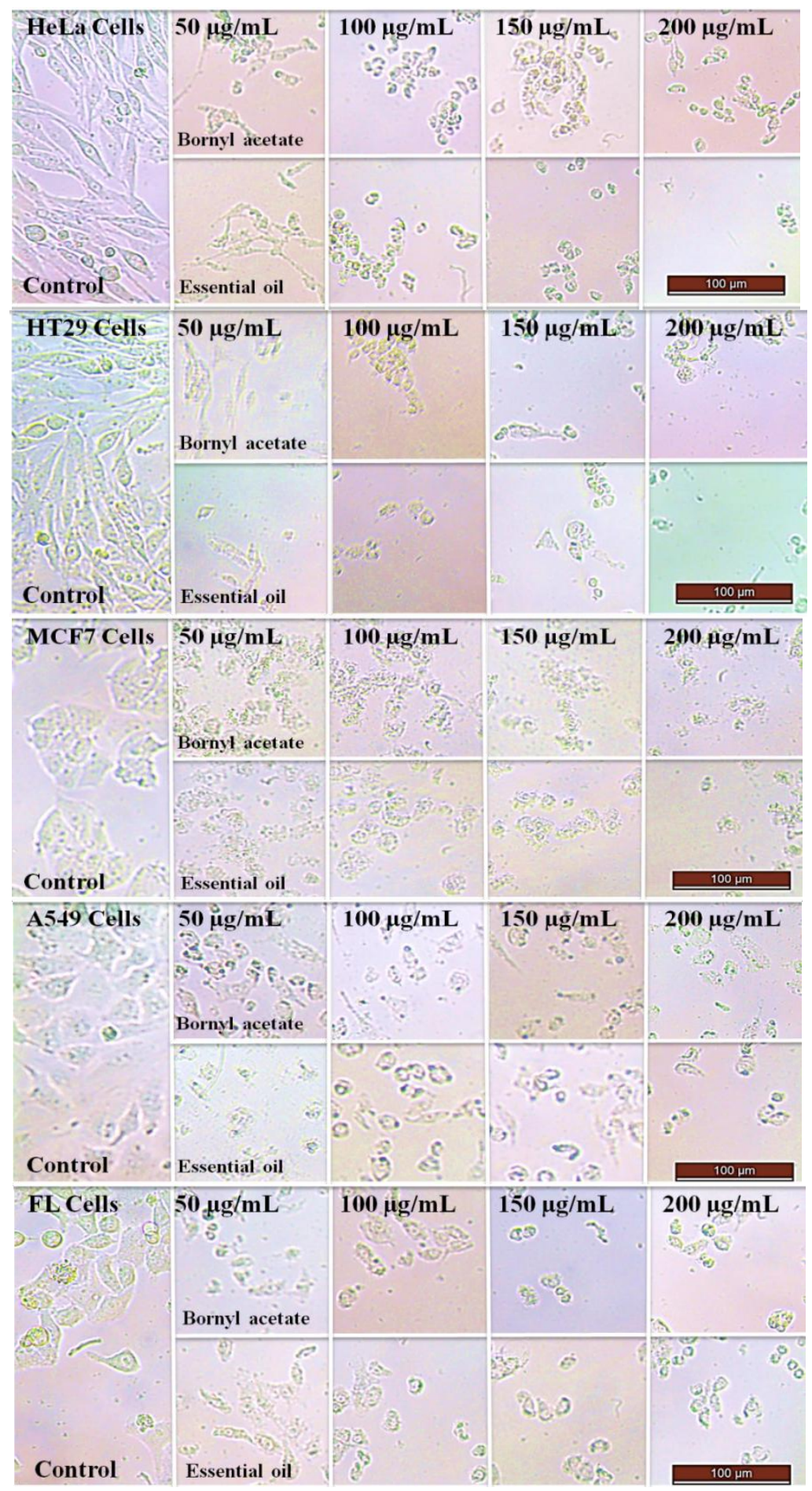

Figure 3. Effect of the essential oil and bornyl acetate of inula graveolens on the morphology of HeLa, HT29, A549, MCF7 and FL cells. Exponentially growing cells were incubated with various concentrations of essential oil and bornyl acetate at $37{ }^{\circ} \mathrm{C}$ for overnight. DMSO treated cells as controls.

In this work, cell growth and inhibition, and cellular morphological analysis indicated that in all tumor cells a dose-dependent decline was induced by essential oil and bornyl acetate. A fundamental 
factor of tumor cell survival is resistance to apoptosis. As a result, Inula graveolens essential oil has a potency to be an anti-cancer agent. Moreover, it could be used in food and pharmaceutical industries.

\section{ORCID}

Tunay Karan: 0000-0002-9114-8400

Ilyas Yildiz: 0000-0003-1254-1069

Ali Aydin: 0000-0002-9550-9111

Ramazan Erenler: 0000-0002-0505-3190

\section{References}

[1] A. Ertas, A. C. Gören, N. Hasimi, V. Tolan and U. Kolak (2015). Evaluation of antioxidant, cholinesterase inhibitory and antimicrobial properties of Mentha longifolia subsp. noeana and its secondary metabolites, Rec. Nat. Prod 9, 105-115.

[2] R. Erenler, S. Yilmaz, H. Aksit, O. Sen, N. Genc, M. Elmastas and I. Demirtas (2014). Antioxidant activities of chemical constituents isolated from Echinops orientalis Trauv., Rec. Nat. Prod. 8, 32-36.

[3] R. Erenler, O. Sen, I. Yildiz and A. Aydin (2016). Antiproliferative activities of chemical constituents isolated from Thymus praecox subsp grossheimii (Ronniger) Jalas, Rec. Nat. Prod. 10, 766-770.

[4] Y. M. Zhao, M. L. Zhang, Q. W. Shi and H. Kiyota (2006). Chemical constituents of plants from the genus Inula, Chem. Biodivers. 3, 371-384.

[5] A. M. Seca, A. Grigore, D. C. Pinto and A. M. Silva (2014). The genus Inula and their metabolites: From ethnopharmacological to medicinal uses, J. Ethnopharmacol. 154, 286-310.

[6] W. T. Parsons and E. G. Cuthbertson (2001). Noxious weeds of Australia: CSIRO publishing.

[7] X. Han, L. Yin, L. Xu, X. Wang and J. Peng (2010). Simultaneous determination of ten active components in chinese medicine "huang-lian-shang-qing" tablets by high-performance liquid chromatography coupled with photodiode array detection, Anal. Lett. 43, 545-556.

[8] S. Nikolaev, V. Khobrakova, T. Azhunova, P. Lubsandorzhieva, L. K. Mukhanova and A. Unagaeva (2006). Immunomodulating effect of the antiulcerous drug ventrofit, Pharm. Chem. J. 40, 501-503.

[9] O. Danino, H. E. Gottlieb, S. Grossman and M. Bergman (2009). Antioxidant activity of 1, 3dicaffeoylquinic acid isolated from Inula viscose, Food Res. Int. 42, 1273-1280.

[10] N. Merghoub, S. Amzazi and H. Morjani (2009). Cytotoxic effect of some Moroccan medicinal plant extracts on human cervical cell lines, J. Med. Plants. Res. 3, 1045-1050.

[11] C. Xie, H. Wang, X. Sun, L. Meng, M. Wang, M. Bartlam and Y. Guo (2015). Isolation, characterization, and antiproliferative activities of eudesmanolide derivatives from the flowers of Inula japonica, J. Agr. Food Chem. 63, 9006-9011.

[12] R. P. Singh, R. Singh, P. Ram and P. G. Batliwala (1993). Use of Pushkar-Guggul, an indigenous antiischemic combination, in the management of ischemic heart disease, Int. J. Pharmacog. 31, 147160.

[13] S. Manez, M. del Carmen Recio, I. Gil, C. Gómez, R.-M. Giner, P. G. Waterman and J.-L. Ríos (1999). A -glycosyl analogue of diacylglycerol and other antiinflammatory constituents from Inula viscosa, $J$. Nat. Prod. 62, 601-604.

[14] L. Lauro and C. Rolih (1990). Observations and research on an extract of Inula viscosa Ait, Boll. Soc. Ital. Biol. Sper. 66, 829-834.

[15] W. Wang, B. Ben-Daniel and Y. Cohen (2004). Control of plant diseases by extracts of Inula viscosa, Phytopathology 94, 1042-1047.

[16] H. B. Boudouda, A. Benmerache, S. Chibani, A. Kabouche, S. Abuhamdah, Z. Semra and Z. Kabouche (2012). Antibacterial activity and chemical composition of essential oils of Inula viscosa (L.) Ait.(Asteraceae) from Constantine, Algeria, Pharm. Lett. 4, 1863-1867.

[17] Y. Oka, B.-H. Ben-Daniel and Y. Cohen (2006). Control of Meloidogyne javanica by formulations of Inula viscosa leaf extracts, J. Nematol. 38, 46.

[18] Y. Oka, B.-H. Ben-Daniel and Y. Cohen (2001). Nematicidal activity of powder and extracts of Inula viscosa, Nematology 3, 735-742.

[19] S.-D. Zhang, J.-J. Qin, H.-Z. Jin, Y.-H. Yin, H.-L. Li, X.-W. Yang, X. Li, L. Shan and W.-D. Zhang (2012). Sesquiterpenoids from Inula racemosa Hook. f. inhibit nitric oxide production, Planta Med. 78, $166-171$.

[20] X.-R. Cheng, W.-W. Li, J. Ren, Q. Zeng, S.-D. Zhang, Y.-H. Shen, S.-K. Yan, J. Ye, H.-Z. Jin and W.D. Zhang (2012). Sesquiterpene lactones from Inula hookeri, Planta Med. 78, 465-471. 
[21] J.-J. Qin, J.-X. Zhu, Q. Zeng, X.-R. Cheng, Y. Zhu, S.-D. Zhang, L. Shan, H.-Z. Jin and W.-D. Zhang (2011). Pseudoguaianolides and guaianolides from Inula hupehensis as potential anti-inflammatory agents, J. Nat. Prod. 74, 1881-1887.

[22] J.-J. Qin, J.-X. Zhu, Q. Zeng, X.-R. Cheng, S.-D. Zhang, H.-Z. Jin and W.-D. Zhang (2012). Sesquiterpene lactones from Inula hupehensis inhibit nitric oxide production in RAW264. 7 macrophages, Planta Med. 78, 1002-1009.

[23] H.-B. Zhang, J.-K. Wen, J. Zhang, S.-B. Miao, G.-Y. Ma, Y.-Y. Wang, B. Zheng and M. Han (2011). Flavonoids from Inula britannica reduces oxidative stress through inhibiting expression and phosphorylation of p47phox in VSMCs, Pharm. Biol. 49, 815-820.

[24] W. H. Talib, M. H. A. Zarga and A. M. Mahasneh (2012). Antiproliferative, antimicrobial and apoptosis inducing effects of compounds isolated from Inula viscosa, Molecules 17, 3291-3303.

[25] V. Mitic, V. Stankov Jovanovic, M. Ilic, O. Jovanovic, A. Djordjevic and G. Stojanovic (2016). Dittrichia graveolens (L.) Greuter essential oil: Chemical composition, multivariate analysis, and antimicrobial activity, Chem. Biodivers. 13, 85-90.

[26] N. Aghel, A. Z. Mahmoudabadi and L. Darvishi (2011). Volatile constituents and anti candida activity of the aerial parts essential oil of Dittrichia graveolens (L.) Greuter grown in Iran, Afr. J. Pharm. Pharmacol. 5, 772-775.

[27] S. Dohi, M. Terasaki and M. Makino (2009). Acetylcholinesterase inhibitory activity and chemical composition of commercial essential oils, J. Agr. Food. Chem. 57, 4313-4318.

[28] H. B. Boudouda, A. Kabouche, T. Aburjai and Z. Kabouche (2013). GC-MS Analysis of Inula graveolens (L.) Desf. from Algeria, J. Essent. Oil Bear. Pl. 16, 651-654.

[29] B. E. Abu Irmaileh, A. M. F. Al-Aboudi, M. H. Abu Zarga, F. Awwadi and S. F. Haddad (2015). Selective phytotoxic activity of 2,3,11 beta,13-tetrahydroaromaticin and ilicic acid isolated from Inula graveolens, Nat. Prod. Res. 29, 893-898.

[30] S. Öksüz and G. Topçu (1992). A eudesmanolide and other constituents from Inula graveolens, Phytochemistry 31, 195-197.

[31] G. Topçu, S. Öksüz, H.-L. Shieh, G. A. Cordell, J. M. Pezzuto and C. Bozok-Johansson (1993). Cytotoxic and antibacterial sesquiterpenes from Inula graveolens, Phytochemistry 33, 407-410.

[32] J. Ferlay, I. Soerjomataram, R. Dikshit, S. Eser, C. Mathers, M. Rebelo, D. M. Parkin, D. Forman and F. Bray (2015). Cancer incidence and mortality worldwide: sources, methods and major patterns in GLOBOCAN 2012, Int. J. Cancer 136, 359-386.

[33] B. Bayir, H. Gündüz, T. Usta, E. Şahin, Z. Özdemir, Ö. Kayır, Ö. Sen, H. Akşit, M. Elmastaş and R. Erenler (2014). Chemical composition of essential oil from Marrubium vulgare L. leaves, J. New Results Sci. 6, 44-50.

[34] G. Kaya, R. Karakaya, E. Tilgel, M. Sandikci, E. Yucel, G. Cicek, O. Kayir, H. Aksit, I. Telci and A. Guzel (2014). Essential oil constituents of Thuja orientalis berries, J. New. Results. Sci. 7, 1-6.

[35] R. Erenler, B. Meral, O. Sen, M. Elmastas, A. Aydin, O. Eminagaoglu and G. Topcu (2017). Bioassayguided isolation, identification of compounds from Origanum rotundifolium and investigation of their antiproliferative and antioxidant activities, Pharm. Biol. 55, 1646-1653.

[36] M.M. Uremis, A.S.Yaglioglu, Y. Budak, M. Ceylan (2017). Synthesis, characterization, in vitro antiproliferative and cytotoxicity effects of a new class of 2-((1R,2S)-2-((E)-4-substitutedstyryl) cyclooctyl)benzo[d] thiazole derivatives, Org. Commun, 10:3, 190-200.

[37] T. Mosmann (1983). Rapid colorimetric assay for cellular growth and survival: application to proliferation and cytotoxicity assays, J. Immunol. Methods. 65, 55-63.

[38] R. Erenler, K. Pabuccu, A. S. Yaglioglu, I. Demirtas and F. Gul (2016). Chemical constituents and antiproliferative effects of cultured Mougeotia nummuloides and Spirulina major against cancerous cell lines, Z. Naturforsch. C. 71, 87-92.

[39] T. Decker and M.-L. Lohmann-Matthes (1988). A quick and simple method for the quantitation of lactate dehydrogenase release in measurements of cellular cytotoxicity and tumor necrosis factor (TNF) activity, J. Immunol. Methods. 115, 61-69.

[40] R. Erenler, O. Sen, A. S. Yaglioglu and I. Demirtas (2016). Bioactivity-guided isolation of antiproliferative sesquiterpene lactones from Centaurea solstitialis L. ssp. solstitialis, Comb. Chem. High Throughput. Screen. 19, 66-72.

[41] S. Okten, R. Erenler, T. K. Koprulu and S. Tekin (2015). In vitro antiproliferative/cytotoxic activity of 2,3 '-biindole against various cancer cell lines, Turk. J. Biol. 39, 15-22.

[42] A. Scalbert, C. Manach, C. Morand, C. Rémésy and L. Jiménez (2005). Dietary polyphenols and the prevention of diseases, Crit. Rev. Food. Sci. 45, 287-306.

[43] M. Ambroz, P. Matouskova, A. Skarka, M. Zajdlova, K. Zakova and L. Skalova (2017). The effects of selected sesquiterpenes from Myrica rubra essential oil on the efficacy of doxorubicin in sensitive and resistant cancer cell lines, Molecules 22, 1-10. 
[44] Y. Zhao, R. Chen, Y. Wang, C. Qing, W. Wang and Y. Yang (2017). In vitro and in vivo efficacy studies of Lavender angustifolia essential oil and its active constituents on the proliferation of human prostate cancer, Integr. Cancer. Ther. 16, 215-226.

[45] F. Öke Altuntaş and İ. Demirtaş (2017). Real-time cell analysis of the cytotoxicity of Origanum acutidens essential oil on HT-29 and HeLa cell lines, Turk. J. Pharm. Sci. 14, 29-33.

[46] T. A. Sani, E. Mohammadpour, A. Mohammadi, T. Memariani, M. V. Yazdi, R. Rezaee, D. Calina, A. O. Docea, M. Goumenou, L. Etemad and S. Shahsavand (2017). Cytotoxic and apoptogenic properties of Dracocephalum kotschyi aerial part different fractions on CALU-6 And MEHR-80 lung cancer cell lines, Farmacia 65, 189-199.

[47] L. T. García, A. F. Leal, É. M. Moreno, E. E. Stashenko and H. J. Arteaga (2017). Differential antiproliferative effect on K562 leukemia cells of Lippia alba (Verbenaceae) essential oils produced under diverse growing, collection and extraction conditions, Ind. Crop. Prod. 96, 140-148.

[48] R. P. Adams (2007). Identification of Essential Oil Components by Gas Chromatography/Mass Spectrometry, Illinois, USA: Allured Publishing Corporation, Carol Stream.

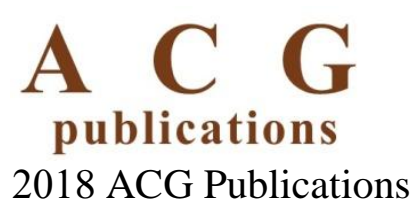

